\title{
The Impact of Audit Committee Diligence on Modification of Audit Opinion: State Owned Enterprises in Kenya.
}

\author{
Mongeri Oruke $^{1 *}$ Cyrus Mwangi Iraya ${ }^{2}$ Nixon Oluoch Omoro ${ }^{2}$ Luther Odhiambo Otieno ${ }^{2}$ \\ $1 \mathrm{PhD}$ Student School of Business, University of Nairobi, Kenya \\ 2.School of Business, University of Nairobi, Kenya
}

\begin{abstract}
The study examined the effect of audit committee meetings as a proxy for audit committee diligence on modification of audit opinion in commercial and manufacturing state owned enterprises in Kenya. The study examined data from 28 companies in the commercial and manufacturing sector covering the period of 2007 to 2016. The data was analysed using a logistic regression model. The study established significant negative relationship between number of audit committee meetings as proxy for audit committee diligence and modified audit opinion. The study findings imply that increased number of audit committee meetings reduced the likelihood of receiving modified audit opinion. This means increased quality of supervision by diligent audit committee led to improved quality of financial reporting. Diligent monitoring could reduce opportunistic behaviours by management as suggested by the agency theory. The findings from this study will contribute significantly practitioners in corporate governance in the public sector to be more diligent in order to improve quality of financial reporting. In addition, the findings will be beneficial to both internal and external auditors to engage with audit committee to ensure smooth audit process and reporting.
\end{abstract}

Key Words: Modified Audit Opinion, Audit committee diligence, Firm size, State Owned enterprises.

DOI: $10.7176 /$ RJFA/12-6-10

Publication date:March $31^{\text {st }} 2021$

\subsection{Introduction}

Corporate governance has become an important topic in both private and public sectors. This is in response to corporate financial scandals that has forced stakeholders to rethink the governance mechanisms. Globally, countries have responded differently: some through regulations, laws and even codes of corporate governance. Notable cases include the Oxley and Sarbanes (2002) act in the United states of America and (Cadbury, 1992) report in United Kingdom.

In Kenya the government incorporated the Mwongozo (2015) code of corporate governance for state corporations to promote accountability in state corporations. This was introduced after collapse and poor performance of several state owned entities. The Mwongozo code (2015) puts the board at the epicenter of corporate governance. Specifically, Mwongezo code states that a functional board should have audit committee as key sub-committee of the board. The Mwongozo code assigns the audit sub-committee with the responsibility of dealing with external audit, internal audit, internal controls, risk management and financial reporting in state owned enterprise. A diligent and functional audit subcommittee is expected to greatly promote accountability and transparency in state owned enterprise resulting to quality financial reporting. This will be evidenced by clean or unmodified audit reports being issued by the independent auditors. The World Bank (2014) toolkit for state owned corporation advocates as good practice an affective board should have audit sub-committee responsible for managing audit and risk in the board.

\subsubsection{Audit committee in State Owned Entities in Kenya}

The corporate governance in Kenya state owned entities is spelled out in Mwongozo code of corporate governance for state corporation. Mwongozo code (2015) states that all boards should have an audit committee responsible for overseeing external and internal audit. The audit committee is key in interrogating external audit reports and resolve material findings. The World Bank (2014) toolkit for corporate governance for state owned enterprises supports the argument that audit committee could improve corporate governance for state owned enterprises. These include improvement in internal controls, compliance and financial reporting guidelines. This is likely to improve quality of financial reporting leading to unmodified audit opinions. Similarly, OECD (2015) guidelines for governance for state owned entities supports the argument.

To perform their duties sufficiently Mwongozo proposes that at least the audit committee should meet frequently. Audit committee diligence is measured as the activity or the number of committee meeting based on prior studies (Saaydah, 2019; Farinha \& Viana, 2009; Raghunandan \& Dasaratha , 2007). The increased activity by the audit committee is expected to improve review of information presented by management thus help reduce information asymmetry. In addition, increased activity will ensure that effective internal control systems are put in place 
through interaction with internal audit function. Further, material issues raised by external auditors will be addressed.

\subsubsection{Modification of Audit Opinion}

Based on the agency theory auditing function is a corporate governance mechanism employed to reduce agency problem by reducing information asymmetry. The role of management is to prepare financial reports and communicate them through reports. The role of independent auditors is to examine the financial reports and to ensure the information is true and fair. Through audit opinion the independent audit is able to express an opinion on the quality of financial reporting. According Intosai ( 2009) an audit opinion is modified if the financial statements are found not to be free from material misstatements. Audit modification can be categorized into three: qualified, adverse and disclaimer opinion (Hsiao, Lin, \& Hsu, 2010).

In Kenya the Auditor - General is the independent supreme institution (SAI) responsible for auditing financial statements from state owned entities and report through the audit opinion. The auditor general reports to national assembly of Kenya after evaluating the financial statements.

Based on the theoretical framework by the agency theory, the audit committee activity should influence quality of financial reporting. The number of audit committee meetings as a proxy of audit committee diligence is likely to influence the likelihood of receiving modified audit opinion. A diligent Audit committee will have time to monitor and examine information prepared by management leading to quality of financial reporting. However, based on empirical evidence the matter remains unresolved dues contrasting findings based on empirical evidence (Alkilan, Hussin\& Salim, 2019; Saaydah, 2019; Salleh \& Haat; 2014; Farinha \& Viana, 2009).

The study aims to address the following research questions

I. Does audit committee activity influence the likelihood of modification of audit opinion for commercial and manufacturing state owned enterprises in Kenya.

II. Does firm size as control variable influence the relationship between audit committee and modification of audit opinion commercial and manufacturing state owned enterprises in Kenya.

\subsection{Literature Review}

\subsection{Theoretical Foundation}

Due to separation of ownership and control in modern business has led to agency problem (Berle \& Means, 1932). This arises due to information asymmetry between the agents and principal (Jensen \& Meckling, 1976). Corporate governance systems are developed to manage the agency problem. This involve creating systems to monitor and supervise the agent to act in the interest of stakeholders.

Corporate governance reforms in both public and private sectors have brought regulatory frameworks that brings out requirement for involvement of audit committee in the protection of investors. The audit committee mediates between the external audit and management helping in resolving material audit issues in the report which will improve quality of financial reporting. Audit committee therefore is a monitoring mechanism with significant contribution to governance framework (Islam, 2010).

\subsection{Empirical Evidence}

Alkilan, Hussin and Salim (2019) examined the role of audit committtee lessening the likelihood of a firm receiving modified audit opinion in Jordan. The study sampled 117 firms listed at Amman securities exchange covering the period 2012-2017. Audit committee size, expertise, independence and number of meetings as the independent variables were analysed using logistic regression. The study established that audit committee expertise contributed significantly to the likelihood of a firm receiveing modified audit opinion. However, audit committee variables inluding; independent size, number of meetings had insignificant influence on the likelihood of receiving modified opinion in Jordan.

Nelwan and Tansuria (2019) examined the effectiveness of audit committee characteristics in constraning earnings management.The study anaysed data from manufacturing companies covering the period 2009 to 2015 in Indonesia. The study concluded that audit audit committee independence constrained earnings management in Indonesia. In contrast the results for audit committee expertise in constraining earnings management was statistically insignificant.

Inaam and Khamoussi (2016) using meta-analyze methodology analyzed findings of 58 prior studies on the relationship between audit committee as corporate governance mechanism and earnings management. The study established significant relationships between earnings management and audit committee characteristics including: the number of committee meetings, size, independence and expertise of members.

Jatiningrum, Fauzi, Irviani, Mujiyati and Hasan (2020) examined the effect of audit committee on financial 
reporting pre and post adoption of IFRS in Malasyia. The study examined data from 81 companies covering the period 2009 to 2015.The data was analysed using multiple regression method. The study established that after adoption of IFRS significant relationship existed between audit committte and quality of financial reporting.

Raghunandan and Dasaratha (2007) examined determinants of audit committee diligence. The study sampled 319 firms from the S\&P SmallCap60 in 2003. The study established that number of audit committee meeting was the best signal of measuring audit committee diligence. In addition, the study established that larger entities are likely to set diligent audit committee with expertise.

Ali, Noor, Khurshid and Mahmood (2015) examined the effect of firm size on earnings management in Textile company In Pakistan. The study analysed annual data covering the period 2004 to 2013 . Firm size was measured using the logarithm of total assets. The study established that positive and statistical effect of firm size on earnings management.

Salleh and Haat (2014) examined the effectiveness of audit committee in constraining earnings management. The study examined data for 280 companies listed at Bursa Malasyia covering the period 2005 to 2009. The study established that audit committtee characteristics inlcuding firm size, frequency of meetings and independence had a significant impact on earnings management.

\subsection{Conceptual Framework}

\section{Control Variable}

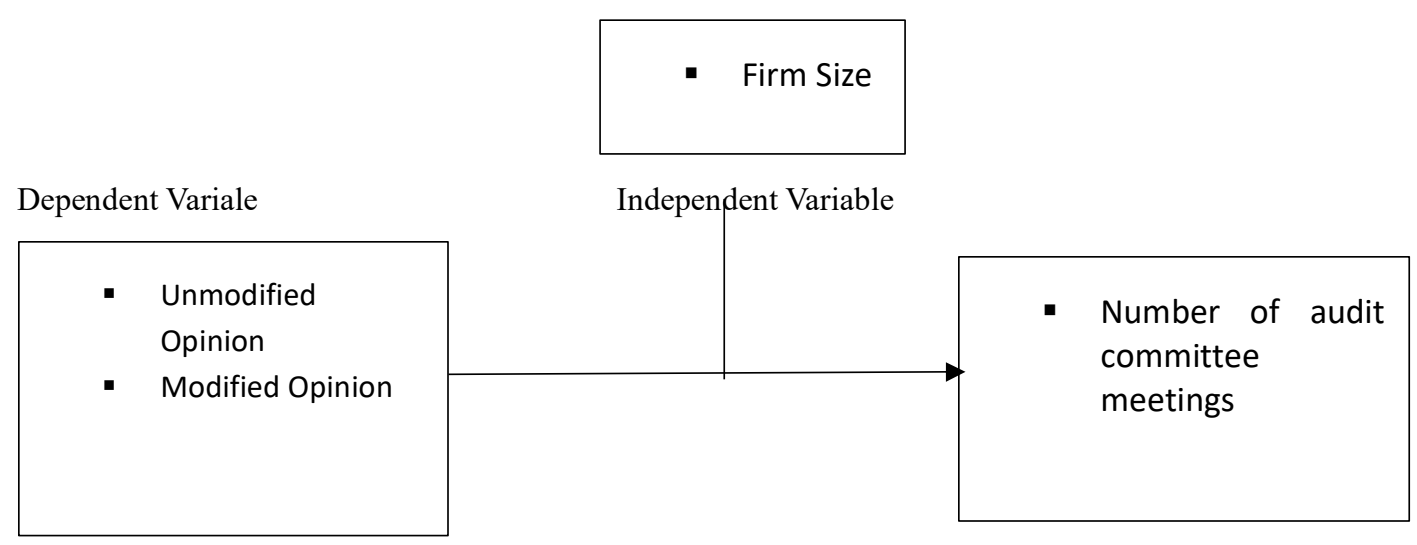

\subsection{Research Hypothesis}

$\mathrm{H}_{1}$ : The number audit committee meetings as a proxy for audit committee diligence had a negative and significant relationship with modified audit opinion in commercial and manufacturing state owned enterprises in Kenya.

$\mathrm{H}_{2}$ : Firm size as a control variable significantly influenced the relationship between audit committtee diligence and modified audit opinion in commercial and manufacturing state owned enterprises in Kenya.

\subsection{Methodology}

\subsection{Research Design}

This study adopted a corretional research design to achieve its ojectives. In a correlational research design the objective is to determine the degree of association among the research variables (Creswell, 2014)

\subsection{Population and Sampling}

The population of study constituted all the thirty-three (33) companies in the commercial and manufacturing sector as categorized by (SCAC, 2021). The study obtained data twenty-five (28) companies indicating a high response rate.

\subsection{Data Collection}

The study collected secondary data relating to the research variables. Data on audit opinion was obtained from the 
audit reports published by the Auditor -General of Kenya covering the period 2007 to 2016. The number of audit committee meetings was obtained corporate governance statements in the annual reports. The information on firm size as control variable was computed using data obtained from annual financial statements.

\subsection{Model Specification}

To test the relationship between the variables the study employed logistic regression model. The model is used instances where the binary outcome is predicted from independent variables. The technique is flexible to accept binary outcomes (Boateng \& Abaye, 2019)

$\mathrm{AO}=\beta_{0}+\beta_{1}$ ACmeetings $+\beta_{3}$ Firm Size $+\varepsilon$

Where:

$\mathrm{AO}=$ Audit Opinion

ACmeetings $=$ the number of audit committee meetings as a proxy for audit committee diligence

$\beta_{0}$ the intercept

$\beta_{\mathrm{n}}$ the coefficient

$\varepsilon$ the error term

Dependent Variable

The audit opinion was taken to be the dependent variables and was operationalized using of coding. The audit unmodified opinion coded as zero (0) while modified opinion coded as zero (1).

\section{Independent Variable}

Number Audit committee meetings as proxy for audit committee diligence based on theoretical framework and empirical evidence was conceptualized to significantly influence quality of financial reporting.

\section{Control Variable}

Firm size as a control variable was operationalised by measuring logarithm of total assests this was based on empirical evidence from prior studies (Ali,Noor,Khurshid \& Mahmood, 2015). It was also conceptualised that large firms had the capacity to set up a fuctional corporate governance structures including audit committtee with relevant expertise and resources to hold regular meetings.

\section{Operationalization of variables}

Table 1. Operationalization of variables

\begin{tabular}{lc}
\hline Variable & Measure \\
\hline Dependent Variable & \\
$\begin{array}{l}\text { Audit opinion } \\
\text { Independent Variable }\end{array}$ & Unmodified "0" modified " $1 "$ \\
$\begin{array}{l}\text { Audit committtee Diligence } \\
\text { Control Variable }\end{array}$ & Number of audit committee meetings \\
Firm Size & Log of total assets \\
\hline
\end{tabular}

\subsection{Results and Discussion}

\subsection{Descriptive Statistics}

\subsection{Frequency Distribution Audit Opinion}

Table 2: Frequency distribution audit opinion

\begin{tabular}{lcc}
\hline & Frequency & Percentage \% \\
\hline "0" Unmodified O & 89 & 32.0 \\
$\begin{array}{l}\text { Opinion } \\
\text { "1" Modified }\end{array}$ & 189 & 68.0 \\
opinion & 278 & 100.0 \\
Total & & \\
\hline
\end{tabular}

Table 2 presents the frequency distribution of the Audit Opinion. Based on the frequency distribution the results indicate that majority of state owned entities received modified audit opinion accounting for $68 \%$ of audit opinions. Only $32 \%$ of audit opinions issued by the auditor-general of Kenya represented unmodified audit opinions or clean reports. This implies that majority of state owned enterprises experienced difficulties on quality of financial 
reporting.

Table 3 :Descriptive Statistics

\begin{tabular}{lcrrrr}
\hline & $\mathrm{N}$ & Minimum & Maximum & \multicolumn{1}{c}{ Mean } & Std. Deviation \\
\hline Firm Size $(\log$ Total assets) & 278 & 5.62 & 11.49 & 8.4469 & 1.40862 \\
$\begin{array}{l}\text { Number of audit committee } \\
\text { meetings }\end{array}$ & 278 & 0 & 11 & 3.79 & 1.884
\end{tabular}

Table 3 presents the descriptive statistics results. The summary shows that on average audit committee activity represented by number of committee meetings average 3.79 meetings with a maximum of 11 meetings with a standard deviation of 1.8. The results for firm size indicate a mean of 8.4 with minimum of 5.6 and maximum of 11.49 with a standard deviation of 1.4 .

\subsection{Diagnostic Tests}

4.3.1 Omnibus Tests

Table 4 : Omnibus Tests of Model Coefficients

\begin{tabular}{lccc}
\hline & Chi-square & df & Sig. \\
\hline Step & 89.603 & 2 & .000 \\
Block & 89.603 & 2 & .000 \\
Model & 89.603 & 2 & .000
\end{tabular}

Table 4 presents the omnibus tests of model coefficients. The results presents Chi -square value of 89.603 that is statistically significant based of $\mathrm{p}$ values. This is an indicator that the model is better than the null model.

\subsubsection{Model Accuracy Predictions \\ Table 5: Classification Table}

\begin{tabular}{lccc}
\hline & & Predicted & \\
\hline Observed & Unmodified opinion & Modified opinion & percentage Correct \\
\hline Modified opinion & 55 & 34 & 61.8 \\
Modified opinion & 31 & 158 & 83.6 \\
Overall Percentage & & & 76.6 \\
\hline
\end{tabular}

a. The cut value is .500

Table 5 presents the classification table results. The tables results predict the model accuracy. Based on the results the model prediction accuracy was 76.6 which is significantly high. This indicated that the model could accurately predict the results.

\subsection{Logistic Regression Results}

Table 6: Model Summary

\begin{tabular}{ccc}
\hline $\begin{array}{c}-2 \text { Log } \\
\text { likelihood }\end{array}$ & Cox \& Snell R Square & Nagelkerke R Square \\
\hline $258.996^{\mathrm{a}}$ & .276 & .386 \\
\hline
\end{tabular}

Estimation terminated at iteration number 5 because parameter estimates changed by less than .001 .

Table 6 presents the model summary. The results reveal Nagelkerke R Square 0.386 which indicates the model is good. The Cox \& Snell R Square 0.276 mean that probability of modified opinion being explained by the model is 27.6 which is significant. 
Table 7: Logistic Regression Results

\begin{tabular}{lrrrrrr}
\hline & B & \multicolumn{1}{c}{ S.E. } & \multicolumn{1}{l}{ Wald } & df & \multicolumn{1}{c}{ Sig. } & \multicolumn{1}{c}{$\operatorname{Exp}(\mathrm{B})$} \\
\hline ACMeetings & -.433 & .092 & 22.076 & 1 & .000 & .648 \\
FirmSize & .760 & .119 & 40.522 & 1 & .000 & 2.138 \\
Constant & -3.698 & 1.012 & 13.355 & 1 & .000 & .025 \\
\hline
\end{tabular}

Table 7 presents the logistic regression results. The audit committee meetings indicate a negative beta $\beta$ of -4.33 with exponential beta of less than 1 Exp 0.68 . statistically significant with $\mathrm{p}$ values $\mathrm{p}$ values $<0.05$. This implies audit committee meeting has a negative relationship with modified opinion. This mean that unit increase in the number of audit committee activity reduced the likelihood of receiving modified audit opinion by a factor of 0.648 . The results for firm size indicate positive beta of $\beta 0.76$ with a positive exponential beta of 2.1 greater than one. This means firm size as control variable significantly influenced the relationship between audit committee diligence and modified audit opinion. This implies that large firms were more likely to receive modified audit opinion.

\subsection{Conclusion and Recommendations}

The study objective was to examine the influence of audit committee diligence on modification of audit opinion in state owned entities. The study collected data from 28 state owned enterprises in commercial and manufacturing sector covering the period 2007 to 2016 . The study established that audit committee activity had a negative and significant influence in modification of audit opinion in state owned entities in Kenya. This study finding implies that increased audit committee activity improved audit committee diligence leading to improved monitoring and review. The results are in agreement with study Salleh and Haat (2014) on effectiveness of audit committee dilligence in constraining opportunistic behaviour of management as argued in agency theory. However, the findings contrasts studies by Alkilan, S. Z., Hussin, W. N., \& Salim, B. (2019). Nelwan, M. L., \& Tansuria, B. I. (2019) on effectiveness of audit committee diligence. The results for firm size as control variable were positive and statistically significant. The findings imply that increased firm size as control variable significantly influenced the relationship between audit committee diligence and modified audit opinion. The study findings on effect of firm size are in agreement with findings from a study by Ali, Noor, Khurshid and Mahmood (2015) on likelihood of management large firms engaging in opportunistic behaviours.

The findings are in agreement with arguments based on agency theory that predicted that audit committee as a governance mechanism could help monitor the agent and ensure information symmetry. The findings are in agreement with the hypothesis that boards with diligent audit are less likely to receive modified audit opinions due to improved quality of financial reporting. Secondly, firm size as control variable reveal positive and significant relationship between firm size and modified audit opinion. This means managers from large firms are likely to engage in opportunistic behaviours due to lower level of supervision by the board of directors.

The findings from this study will contribute significantly to those charged with governance in state owned entities to be more diligent in order to improve quality of financial reporting. In addition, the findings will be beneficial to both internal and external auditors to engage with audit committee to ensure smooth audit process and reporting. The findings will also contribute to literature in the public sector context on issues relating to corporate governance and audit opinion.

\section{References}

Ali, U., Noor, M., Khurshid, M. K., \& Mahmood, A. (2015). Impact of Firm Size on Earnings Management: A Study of Textile Sector of Pakistan. European Journal of Business and Management.

Alkilan, S. Z., Hussin, W. N., \& Salim, B. (2019). The Influence of Audit Committee Characteristics on Modified Audit Opinion in Jordan. Journal of Finance and Accounting, 7(3), 95-106.

Berle, A. A., \& Means, G. C. (1932). The Modern Corporation and Private Property. New York: Macmillan.

Boateng, E. Y., \& Abaye, D. A. (2019). A Review of the Logistic Regression Model with Emphasis on Medical Research. Journal of Data Analysis and information processing, 190-2017.

Cadbury, A. (1992). Report of the Committee on the Financial Aspects of Corporate Governance. London: Gee \& Co. Ltd.

Creswell, J. W. (2014). Research design : qualitative, quantitative, and mixed methods approaches. London: SAGE Publications Ltd.

Farinha, J., \& Viana, L. F. (2009). Board Structure and Modified Audit Opinions: Evidence from the Portuguese Stock Exchange. International Journal of Auditing, 237-258.

Hsiao, H. F., Lin, S. H., \& Hsu, A. C. (2010). Earnings management,corporate governance, and auditor's opinions: 
a financial distress prediction model. Investment Management and Financial Innovations, , 29-40.

Inaam, Z., \& Khamoussi, H. (2016). Audit committee effectiveness, audit quality and earnings management: a meta-analysis. International Journal of Law and Management, 58(2), 179-196.

Intosai. (2009). Forming an Opinion and Reporting on Financial Statements. Vienna: International Organization of Supreme Audit Institutio.

Islam, M. Z. (2010). Agency Problem and the Role of Audit Committee: Implications for Corporate Sector in Bangladesh. International Journal of Economics and Finance, 177-188.

Jatiningrum, C., Fauzi, Irviani, R., Mujiyati, \& Hasan, S. (2020). An investigation on the effect of audit committee on financial reporting in pre and post ifrs adoption: evidence from Malasyian Companies. Humanities \& Social Sciences Reviews, 8(2), 25-35. doi:doi.org/10.18510/hssr.2020.824

Jensen, M. C., \& Meckling, W. H. (1976). Theory of the fi rm: Managerial behavior, agency costs and ownership structure. Journal of Financial Economics, 3(4), 305-360.

Nelwan, M. L., \& Tansuria, B. I. (2019). Audit committee characteristics and earnings management practices. Journal of Economics, Business, and Accountancy, 85-97.

OECD. (2015). OECD Guidelines on Corporate Governance of State-Owned Enterprises. Paris: OECD Publishing.

Oxley, M., \& Sarbanes, P. (2002, February 24). The Sarbanes-Oxley Act 2002. Retrieved from GovTrack.us.: https://www.govtrack.us/congress/bills/107/hr3763

Raghunandan, K., \& Dasaratha, V. R. (2007). Determinants of Audit Committee Diligence. Accounting Horizons, 21(3), 265-279. doi:10.2308/acch.2007.21.3.265

Saaydah, M. (2019). Corporate Governance and the Modification of Audit Opinion: A Study in The Jordanian Market. International Journal of Applied Research in Management and Economics, 28-46.

Salleh, N. H., \& Haat, M. H. (2014). Audit Committee and Earnings Management :Pre and Post MCCG. InternationalReview of Management and BusinessResearch, 307-318.

SCAC. (2021, March 5). State corporation advisory committee. Retrieved from https://www.scac.go.ke/2015-0216-09-44-25/commercial-manufacturing

World Bank. (2014). Corporate Governance of State-Owned Enterprises: A Toolkit. Washington, DC: World Bank. doi:10.1596/978-1-4648-0222-5. 